EXPERTS AND POLITICIANS 


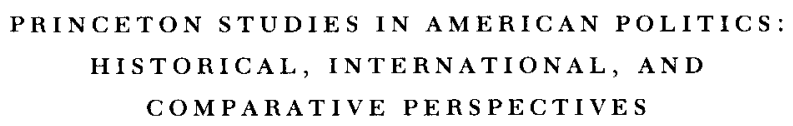

Ira Katznelson, Martin Shefter, Theda Skocpol

\author{
Labor Visions and State Power: The Origins of \\ Business Unionism in the United States \\ by Victoria C. Hattam
}

The Lincoln Persuasion: Remaking American Liberalism by J. David Greenstone

Politics and Industrialization: Early Railroads in the United States and Prussia by Colleen $A$. Dunlavy

Political Parties and the State: The American Historical Experience by Martin Shefter

Experts and Politicians: Reform Challenges to Machine Politics in New York, Cleveland, and Chicago by Kenneth Finegold 


\title{
EXPERTS AND POLITICIANS
}

\author{
REFORM CHALLENGES TO \\ MACHINE POLITICS IN NEW YORK, \\ CLEVELAND, AND CHICAGO
}

Kenneth Finegold 
Copyright (C) 1995 by Princeton University Press Published by Princeton University Press, 41 William Street,

Princeton, New Jersey 08540

In the United Kingdom: Princeton University Press, Chichester, West Sussex All Rights Reserved

\section{Library of Congress Cataloging-in-Publication Data}

Finegold, Kenneth, 1957-

Experts and politicians : reform challenges to machine politics in

New York, Cleveland, and Chicago / Kenneth Finegold.

p. cm. - (Princeton studies in American politics)

Includes bibliographical references and index.

ISBN 0-691-03734-5 (CL : acid-free paper)

1. Elections-New York (N.Y.) 2. New York (N.Y.)-Politics and government-1898-1951. 3. Elections-Illinois-Chicago.

4. Chicago-Cleveland. 6. Cleveland (Ohio)-Politics and government. 7. Populism-United States. 8. Progressivism

(United States politics) I. Title. II. Series.

$$
\text { JS1238.3.F56 } 1995
$$

324.6'3'0973-dc20 94-22109 CIP

This book has been composed in Caledonia

Princeton University Press books are printed on acid-free paper and meet the guidelines for permanence and durability of the Committee on Production Guidelines for Book Longevity of the Council on Library Resources

Printed in the United States of America

$\begin{array}{llllllllll}1 & 3 & 5 & 7 & 9 & 10 & 8 & 6 & 4 & 2\end{array}$ 
IN MEMORY OF MY FATHER

Robert Finegold

APRIL I 7, 1920-MARCH 31, 1989 
